\title{
Fluids trapped within diamond: clues to mantle geochemistry
}

Johnson, L.H. ${ }^{1}$, Burgess, R. ${ }^{1}$, Turner, G. ${ }^{1}$, and Milledge, H.J. ${ }^{2}$.

${ }^{1}$ Dept. of Earth Sciences, University of Manchester, Oxford Rd., Manchester, UK

${ }^{2}$ Dept. of Geological Sciences, University College London, Gower St., London, UK

An extension of the ${ }^{40} \mathrm{Ar}{ }^{39} \mathrm{Ar}$ stepped heating method enables noble gas and halogen $(\mathrm{Br}, \mathrm{Cl}$ and $\mathrm{I})$ contents of $\mathrm{H}_{2} \mathrm{O}-\mathrm{CO}_{3}{ }^{2-}-\mathrm{K}_{2} \mathrm{O}$ rich fluid inclusions (Navon et al., 1988) within diamonds to be measured.

This study compares coated stones with fluid inclusion bearing 'clouds'. Coated stones show constant ${ }^{40} \mathrm{Ar} * / \mathrm{Cl}$ and $\mathrm{Br} / \mathrm{Cl}$ values and limited variations in the $\mathrm{I} / \mathrm{Cl}$ ratio (Burgess and Turner, 1995; Turner et al., 1990; Ozima et al, 1989). Initial results for clouds show variation in the $\mathrm{Br} / \mathrm{Cl}$ and $\mathrm{I} / \mathrm{Cl}$ ratios between high- and low-temperature releases for single stones. This may be a result of the more complicated growth history, as suggested by the nitrogen aggregation states of clouds.

Carbon isotope analyses of cloud diamonds record $\delta^{13} \mathrm{C}$ values of between $-3.4 \%$ to $-8.2 \%$ in general agreement with the globally uniform coated stone established value (Boyd et al., 1994).

Clouds from various kimberlite pipes have been studied; DeBeers Pool (3), Finsch (1), Koffiefontein (5), Venetia (3), and Premier (7); a total of 19. Average sample weight ranges from $5 \mathrm{mg}$ to $40 \mathrm{mg}$. The system blanks are small enough to allow step heating of the diamonds, between $900^{\circ} \mathrm{C}$ and $2150^{\circ} \mathrm{C}$.

All the clouds exhibit very different release patterns compared to coated stones (fig.1). The coat release pattern is characterised by two release peaks, one at low temperature $\left(1600^{\circ} \mathrm{C}\right)$ and one associated with graphitisation $\left(2050^{\circ} \mathrm{C}\right)$. Previous studies on coats (Turner at al, 1990) suggest that the low temperature release at is due to decrepitation of inclusions or radiation damage. Ozima et al., (1989) note that the dominant release is at the graphitisation temperature. The release patterns for clouds are much broader, starting at $900^{\circ} \mathrm{C}$. Often the bulk of the material (in some cases $\sim 80 \% \mathrm{Ar}$, $\mathrm{Br}, \mathrm{Cl})$ is released before graphitisation $\left(2050^{\circ} \mathrm{C}\right)$.

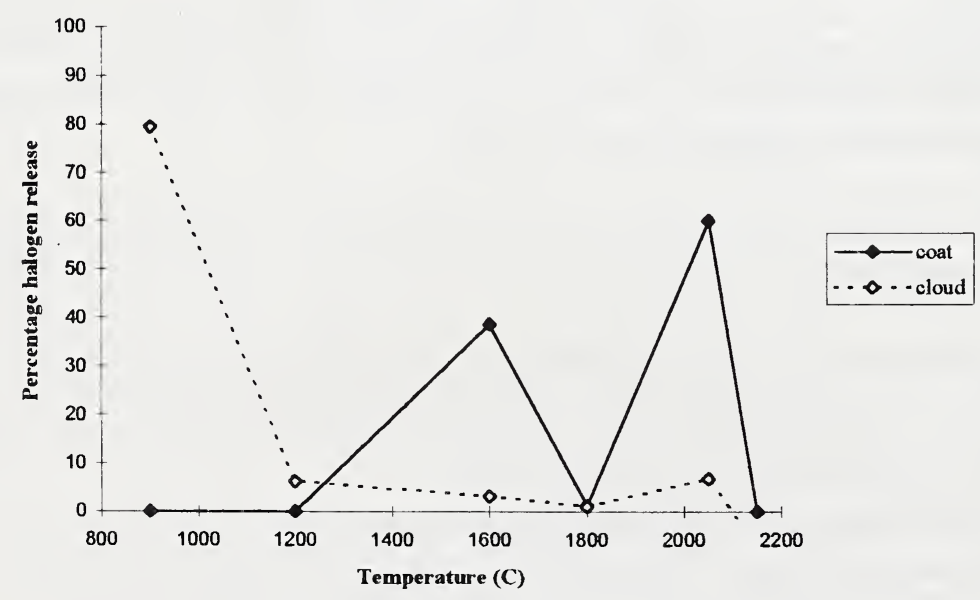

FIG 1. Typical pattern for halogen release (as percentage of the total halogens released) for a coat and a cloud. It is noted that the dominant release is often at low temperatures for clouds. 
Unlike the coats, which exhibit compositional homogeneity across the temperature steps (Turner et al., 1990; Burgess and Turner, 1995), compositional variation is exhibited by clouds. Fig. 2 shows the variation in $\mathrm{Br} / \mathrm{Cl}$ ratio for a typical cloud. The bulk chemical data is presented in Table. 1 for 8 clouds from 2 pipes, outlining the compositional differences that occur within a single pipe. These data show several fluid phases have been trapped within the diamond during multistage growth. This contrasts with the rapid growth of coats.

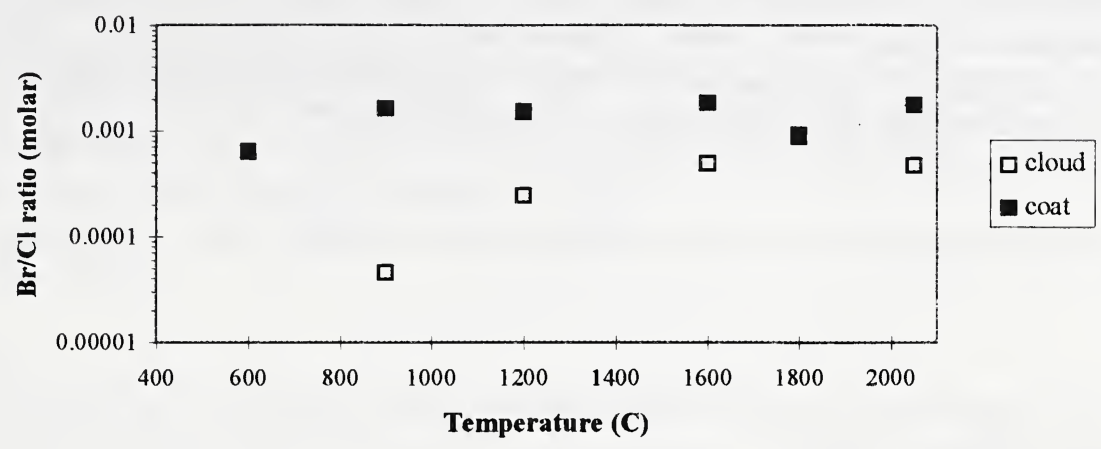

FIG 2. Compositional $(\mathrm{Br} / \mathrm{Cl})$ variations between temperature releases. The $2050^{\circ} \mathrm{C}$ releases are co-incidental for both the coat (solid symbol) and the cloud (open symbol).

Infra-red spectroscopy studies suggest low mantle temperatures and short mantle residence times for coats (Boyd et al., 1987). Preliminary work on clouds (this study) show that increased aggregation states are common for cloud diamond, suggesting a longer mantle residence time and/or higher temperatures.

Separating the fluid component(s) trapped within the clouds will help to resolve questions of mantle heterogeneity and temporal geochemical variations.

$\begin{array}{lcccccc}\text { sample } & \text { weight }(\mathrm{mg}) \mathrm{Cl}(\mathrm{ppm}) & \mathrm{Br} / \mathrm{Cl} & \mathrm{K}(\mathrm{ppm}) & \begin{array}{c}{ }^{40} \mathrm{Ar} * \mathrm{cc} / \mathrm{g} \\ (16\end{array} & \mathrm{Ar} \mathrm{cc} / \mathrm{g} \\ \mathrm{K} 1 & 7.8 & 1.29 & 0.001 & 17.75 & 77 & 3.85 \\ \mathrm{~K} 2 & 9.4 & 0.96 & 0.01 & 13.82 & 7521 & 2.13 \\ \mathrm{~K} 3 & 10.4 & 28.1 & 0.002 & 133.22 & 4346 & 2.88 \\ \mathrm{~K} 4 & 10.5 & 1.0 & 0.02 & 5.61 & 105 & 1.90 \\ & & & & & & \\ \mathrm{P} 1 & 21.1 & 23.9 & 0.003 & 59.07 & 8673 & 4.27 \\ \mathrm{P} 2 & 26.9 & 5.76 & 0.002 & 138.42 & 1346 & 1.12 \\ \mathrm{P} 3 & 37.6 & 1.6 & 0.006 & 19.42 & 1136 & 29.26 \\ \mathrm{P} 4 & 38.7 & 4.02 & 0.002 & 47.00 & 995 & 1.29 \\ & & & & & & \\ \text { Zairel } & 6.4 & 13.8 & & 29.8 & 6990 & 0.30\end{array}$

TABLE 1. Bulk chemical data for 'cloud' samples from two pipes. Koffiefontein, K; Premier, P. Zaire stone (Turner et al., 1990) added for comparison. 


\section{References}

Boyd, S.R., Mattey, D.P., Pillinger, C.T., Milledge, H.J., Mendelssohn, M., and M. Seal, 1987, Multiple growth events during diamond genesis: an integrated study of carbon and nitrogen isotopes and nitrogen aggregation state in coated stones: Earth and Planetary Science Letters, v.86, p. 341-353.

Boyd, S.R. Pineau, F., and Javoy, M. 1994, Modelling the growth of natural diamonds: Chemical Geology, v.116, p. 29-42

Burgess, R., and Turner, G., 1995, Halogen geochemistry of mantle fluids in diamond: Volatiles in the Earth and Solar System, Pasadena, 1995, AIP Conference Proceedings, p. 91-98.

Ozima, M., Zashu, S., Takigami, Y., and Turner, G., 1989, Origin of the anomalous 40Ar-39Ar age of Zaire cubic diamonds: excess 40Ar in pristine mantle fluids: Nature, v. 337, p. 226-229.

Turner, G., Burgess, R., and Bannon, M., 1990, Volatile-rich mantle fluids inferred from inclusions in diamond and mantle xenoliths: Nature, v. 334, p. 653-655. 